\title{
Letramento acadêmico e formação do professor de língua materna: um estudo de caso em um curso de letras
}

\begin{abstract}
Márcia Adriana Dias Kraemer ${ }^{1}$
Programa de Pós-graduação em Letras, Universidade Estadual do Oeste do Paraná - UNIOESTE, Cascavel, Paraná, Brasil

Ramunielly Bonatti Longaretti ${ }^{2}$ Programa de Pós-graduação em Letras, Universidade Tecnológica Federal do Paraná - UTFPR, Pato Branco, Paraná, Brasil
\end{abstract}

Resumo: O objetivo deste estudo é, por meio da análise de pressupostos teóricos e empíricos referentes ao desenvolvimento de capacidades de leitura e de escrita, investigar os processos de letramentos acadêmico-científicos vinculados à formação inicial do professor de língua materna. Para isso, focaliza-se a pesquisa da temática nas experiências de discentes das fases finais do Curso em Letras, Português e Espanhol, Licenciatura, da Universidade Federal da Fronteira Sul, Campus Realeza. Justifica-se o exame pela importância da reflexão acerca de como os professores em formação incorporam-se ao ambiente de práticas sociais situadas em sua área do saber. Os resultados da análise demonstram que: os sujeitos partícipes da investigação apresentam participação periférica legítima como aprendizes, pelas práticas letradas na tríade ensinopesquisa-extensão; a práxis acadêmica possibilita-Ihes a inserção proficiente em comunidades educacionais; os letramentos colaboram tanto à apropriação dos conhecimentos linguístico-pedagógicos quanto à construção de saberes teórico-práticos nos componentes curriculares do Curso.

Palavras-chave: Linguística Aplicada; Formação Inicial; Letramentos Acadêmico-científicos.

Title: Academic Literacy and the Formation of the Mother Tongue Teacher: a case study in a SpanishPortuguese Undergraduation Course

Abstract: The aim of this study is to investigate, through the analysis of theoretical and empirical presuppositions related to the development of reading and writing abilities, the processes of academic and scientific literacy related to the initial formation of the mother tongue teacher. To this end, we focused on the experiences of students of the final years of the

\footnotetext{
${ }^{1}$ Doutora em Estudos da Linguagem pela Universidade Estadual de Londrina - UEL. Estágio Pósdoutoral em andamento no Programa de Pós-graduação em Letras da Universidade Estadual do Oeste do Paraná - UNIOESTE, Campus Cascavel - PR, Bolsa Capes. Professora do Curso de Letras Português e Espanhol - Licenciatura da Universidade Federal da Fronteira Sul - UFFS, Campus Realeza - PR. Orcid: https://orcid.org/0000-0002-8780-7813

E-mail: marcia.kraemer@uffs.edu.br

${ }^{2}$ Mestranda em Letras pela Universidade Tecnológica Federal do Paraná - UTFPR, Campus Pato Branco. Graduada em Letras Português e Espanhol pela Universidade Federal da Fronteira Sul - UFFS, Campus Realeza. Orcid: https://orcid.org/0000-0003-0861-7307

E-mail: ramunielly b@hotmail.com
} 
Portuguese and Spanish Degree at Universidade Federal da Fronteira Sul (Federal University of the Southern Frontier), Campus Realeza. The reflection on how teachers in training are incorporated into the environment of social practices located in their area of knowledge is the reason for this investigation. Our results show that: the subjects participating in the research present legitimate peripheral participation as apprentices, through the practices taught in the teaching-research-extension triad; academic praxis enables them to enter proficiently into educational communities; literacy collaborates both to the appropriation of linguistic-pedagogical knowledge and to the construction of theoretical-practical knowledge in the curricular components of the Course.

Keywords: Applied Linguistics; Initial formation; Academic-scientific Literacy.

\section{Considerações Iniciais}

As pesquisas em letramentos ${ }^{3}$ têm ganhado corpo nas últimas décadas no Brasil, influenciadas por estudos já consolidados em outras partes do mundo. Esse cenário é resultado do novo panorama intelectual acerca da educação no país, em se tratando de ensino e de aprendizagem. As necessidades no âmbito educacional contemplam muito mais do que apenas o ler e o escrever para a escola-academia, mas sim, o desenvolvimento de habilidades letradas para as práticas sociais.

Essa percepção resulta do fato de a sociedade, hoje, encontrar-se na pósmodernidade - considerada um fenômeno social, econômico e cultural, concomitante à chamada III Revolução Industrial, a biotecnológica. Contemporaneamente, os modelos paradigmáticos redimensionam-se da produção para o consumo, sendo o capital potencializado. O efeito é a fragmentação do cenário cultural de classe, de gênero, de sexualidade, de etnia, de raça e de nacionalidade.

Os sujeitos, nesse contexto, demonstram um perfil comportamental voltado às questões individuais e não coletivas. Perde-se a identidade pessoal, desacreditando-se de que o sujeito seja integrado ao meio. A sensação de perda é geralmente denominada de deslocamento ou descentração do sujeito: "Esse duplo deslocamento - descentração dos indivíduos tanto de seu lugar no mundo social e cultural quanto de si mesmos - constitui uma 'crise de identidade' para o indivíduo." (HALL, 1997, p. 9).

Essa fragmentação dos diferentes âmbitos do homem contemporâneo universaliza-se em todos os segmentos sociais, por conseguinte, na educação. Para Adorno, na expressão da indústria cultural, fruto da contemporaneidade, há o mascaramento tanto da crítica quanto

\footnotetext{
${ }^{3} \mathrm{O}$ termo letramentos surge nas reflexões dos Novos Estudos do Letramento (NEL), para abarcar o conjunto de múltiplas práticas sociais que envolvem a produção de leitura e de escrita, em contraposição ao termo letramento, no singular, que pode ser considerado restrito, pois ignora as inúmeras possibilidades de variação em diferentes domínios, linguagens, situações, tempo e contextos. É próximo ao conceito de multiletramentos, de autores filiados ao The New London Group (1996), em que se considera a leitura e a escrita como construídas tanto por recursos verbais como semióticos (visuais, auditivos e espaciais) (STREET, 2014; KLEIMAN, 2008; SOARES, 2003).
} 
do respeito. Isso porque a primeira cede ao conhecimento mecânico e o segundo ao culto ao efêmero da celebridade (ADORNO, 2002). De acordo com o filósofo, a cultura mercadológica é alienante, porque os que dela dispõem reprimem tudo o que possa fazer com que fuja à imanência total da sociedade vigente, permitindo apenas o que serve aos seus propósitos.

Nesse prisma, refletindo o momento contemporâneo, dialético, em que vida, história, cultura e educação interagem, contradizem-se, aproximam-se e mudam, pelo movimento ininterrupto do devir, há a fragmentação da educação nas sociedades complexas. Em virtude, o sujeito caracteriza-se como descentrado, deslocado, uma vez que seu perfil identitário está em movimento contínuo, influenciado pela multiplicidade dos sistemas de significação e de representação cultural.

Este estudo ${ }^{4}$, com efeito, propõe-se a refletir acerca dos efeitos do contexto vigente nas práticas discursivas de acadêmicos do Curso em Letras, Português e Espanhol, Licenciatura, da Universidade Federal da Fronteira Sul - UFFS, Campus Realeza, no Estado do Paraná, Brasil.

Analisam-se os processos de letramentos a que estão sujeitos os estudantes das fases finais do Curso, mediados pelos docentes que atuam especificamente nessa área da linguagem, no período de 2018, com subsídios teóricos de autores que se filiam à Teoria da Atividade $^{5}$, à Análise Dialógica do Discurso ${ }^{6}$ e aos Novos Estudos de Letramento ${ }^{7}$, sob a perspectiva da Linguística Aplicada ${ }^{8}$.

\footnotetext{
${ }^{4}$ Esta investigação, aprovada pelo Comitê de Ética em Pesquisa da Universidade Federal da Fronteira Sul - UFFS, sob o Certificado de Apresentação para Apreciação Ética - CAAE de n. 82379918.3.0000.5564, é resultado parcial do Projeto de Pesquisa Estudos Dialógicos e Práticas de Linguagem em Educação: ensino, aprendizagem e formação reflexiva do sujeito social, da Universidade Federal da Fronteira Sul - UFFS, Campus Realeza, coordenado pela Prof. a Dr. a Márcia Adriana Dias Kraemer. Também faz parte dos estudos relacionados ao Projeto de Pesquisa Interinstitucional Estudos Dialógicos da Linguagem: contribuições para pesquisas em linguística aplicada nos contextos escolares e não-escolares, vinculado ao Programa de Pós-graduação em Letras da Universidade Estadual do Oeste do Paraná - UNIOESTE, Campus Cascavel -PR, coordenado pela Prof.a Dr.a Terezinha da Conceição Costa-Hubes.

${ }^{5}$ A Teoria Histórico-cultural da Atividade - mais conhecida como Teoria da Atividade (TA), respaldada nos estudos de Vigotski (2001[1934]) e de expoentes teóricos da Psicologia na Educação da Escola Russa, como Leontiev (1977), Luria (1977), Rubinstein (1977), Davidov (1988) entre outros -, corresponde a uma filosofia do âmbito psicolinguístico e pedagógico. Analisa as práticas sociais, por meio da interação entre o indivíduo e o ambiente, mediadas por ferramentas que influenciam tanto a natureza do comportamento externo quanto o funcionamento mental interno dos sujeitos. Considera que, conforme a mediação da práxis, ampliam-se ou limitam-se as capacidades do sujeito social de resolver situações nos diferentes âmbitos do conhecimento. A partir dessa perspectiva, constrói-se o conceito, contemporaneamente, de comunidades de prática, também tratado neste artigo, referenciando um conjunto de pessoas que interagem em prol de um mesmo objetivo, para resolver situações de interesse comum (LAVE; WENGER, 1991).

${ }^{6}$ Denominação cunhada por Brait para o conjunto das obras do Círculo de Bakhtin, o qual motiva o surgimento "[...] de uma análise/teoria dialógica do discurso, perspectiva cujas influências e consequências são visíveis nos estudos linguísticos e literários e, também, nas Ciências Humanas de maneira geral." (BRAIT, 2006, p. 09-10).
} 
A triangulação de teorias torna-se pertinente, uma vez que condiz com a perspectiva pós-moderna de pesquisas em educação, ao buscar entender questões relativas à natureza social e educacional dos processos de ensino e de aprendizagem de línguas. Atua na interação dialógica própria da Linguística Aplicada (LA) contemporânea, um campo transdisciplinar de estudo da linguagem em uso que dialoga com diferentes áreas do saber. O construto teórico mostra-se fundamental para os pesquisadores interessados em compreender fenômenos linguísticos na atualidade (MOITA LOPES, 1994).

Logo, a escolha da linha teórica que serve de escopo para este estudo justifica-se, porque procura explicar, de forma geral, como a atividade humana constitui-se e como as práticas sociais influenciam as ações do homem. Por conseguinte, os diferentes processos de letramento demonstram a pluralidade semiótica que permeia o seio social ideologicamente ${ }^{9}$ (BAKHTIN, 2003 [1979]; VOLOCHÍNOV, 2013).

De forma interdisciplinar, essas linhas defendem que os processos de leitura e de escrita são construídos em uma perspectiva sociocultural de práticas sociais. A partir de investigações etnográficas, buscam entender como as ações de letramento acontecem em diversos contextos - escolares e não escolares. Também, demonstram que as relações humanas organizam-se em campos específicos e sistematizados da atividade humana, considerando-se que as práticas sociais são condicion sine quibus non ao entendimento dessas ações e das maneiras de mediá-las.

Diante disso, o problema de pesquisa propõe a seguinte questão: em que medida os acadêmicos das fases finais do Curso em Letras da UFFS apresentam participação periférica legítima ${ }^{10}$ como aprendizes, por meio dos letramentos, em particular o acadêmico/científico, para sua inserção profícua em uma comunidade de prática docente?

\footnotetext{
${ }^{7}$ Os Novos Estudos do Letramento (NEL), em inglês The New Literacy Studies (NLS), "[...] represents a new tradition in considering the nature of literacy, focusing not so much on acquisition of skills, as in dominant approaches, but rather on what it means to think of literacy as a social practice [...] This entails the recognition of multiple literacies, varying according to time and space, but also contested in relations of power. NLS, then, takes nothing for granted with respect to literacy and the social practices with which it becomes associated, problematizing what counts as literacy at any time and place and asking 'whose literacies' are dominant and whose are marginalized or resistant." (STREET, 2003a).

${ }^{8}$ Adota-se "[...] a tendência de pesquisa em Linguística Aplicada (MOITA LOPES, 1992), cujo cerne do processo dialético de ensinar e de aprender concentra-se em dois modos de investigação: a pesquisa de diagnóstico, em que [se focalizam] os acontecimentos da sala de aula, e a pesquisa de intervenção, em que [se vislumbra] uma possibilidade de modificar a situação existente em sala de aula." (KRAEMER, 2014b, p. 31-32). "[...] a Linguística Aplicada [é] propiciadora de análises de caráter interdisciplinar, com investigação, problematização e busca de soluções para questões de linguagem inseridas nas práticas sociais." (KRAEMER, 2014b, p.48).

9 "Por ideologia entendemos todo o conjunto de reflexos e interpretações da realidade social e natural que se sucedem no cérebro do homem, fixados por meio de palavras, desenhos, esquemas ou outras formas sígnicas." (VOLOCHÍNOV, 2013, p. 138)[grifo do autor].

${ }^{10}$ Participação periférica legítima refere-se a atividades situadas com características de um processo de aprendizagem que descreve de forma analítica o engajamento e a participação dos aprendizes nas
} 
A hipótese pressuposta é a de que os discentes dessa etapa educacional demonstrem participação periférica legítima como aprendizes, uma vez que o professor em formação deve desenvolver capacidades relativas aos letramentos "[...] em atividades concretas mediadas por especialistas em sua comunidade de prática, em que as responsabilidades em relação à produção linguística são gradativamente progressivas, expandindo-se ao longo do percurso [...]" (KRAEMER, 2014a, p. 18).

Assim, tem-se, como objetivo geral, a análise dos pressupostos teóricos delimitados, a fim de responder com adequação à questão problematizadora do estudo. Os objetivos específicos, por sua vez, propõem-se a:

a) Estudar as premissas acerca das concepções de língua e de linguagem e sua interação com a formação docente, com foco nos processos de letramento acadêmico-científico, por meio da Teoria da Atividade, da Análise Dialógica do Discurso e dos Novos Estudos do Letramento, subsidiados pela Linguística Aplicada ${ }^{11}$;

b) Investigar as práticas de letramento acadêmico/científico nas fases finais do Curso de Letras da UFFS, com ênfase na participação periférica legítima dos aprendizes em sua comunidade de prática, bem como na percepção docente sobre essa realidade.

O trabalho justifica-se, portanto, no atual cenário de ensino e de aprendizagem de língua materna, uma vez que a constituição de sujeitos letrados na esfera acadêmica, como em outros processos linguísticos, é sinônimo de interação dialógica e de uso da língua na prática social. Nesse sentido, a pesquisa é viável e coerente, em virtude de ter, como campo investigativo, os acadêmicos do Curso em Letras da UFFS, Campus Realeza, bem como os docentes que auxiliam na construção do corpus, tornando-se passível de mensuração, visto que as investigadoras têm proximidade com o objeto de pesquisa.

Para a melhor organização e clareza do caminho da pesquisa, este artigo, de divulgação científica, estrutura-se a partir de duas etapas: na primeira, apresenta-se a reflexão acerca das teorias que fundamentam o estudo; na segunda, expõem-se a análise e a interpretação das práticas de letramento acadêmico-científico nas fases finais do Curso em Letras da UFFS, com ênfase na investigação acerca da participação periférica legítima dos aprendizes em sua comunidade de prática docente.

práticas de trabalho e nas comunidades de prática. Logo, adere-se à aprendizagem para se tornar participante pleno e ativo na comunidade de prática a que pertence ou pretende se inserir (LAVE; WENGER, 1991).

${ }^{11}$ A partir deste momento, utilizar-se-ão as seguintes abreviaturas: TA para Teoria da Atividade; ADD para Análise Dialógica do Discurso; LA para Linguística Aplicada; NEL para Novos Estudos sobre o Letramento. 


\section{Letramentos e Práticas Docentes: ações reflexivas na formação inicial de professores de Língua Portuguesa.}

O fio condutor do estudo está ligado ao papel da linguagem, no contexto da formação reflexiva, o qual também passa firmemente pela concepção linguística adotada. Se a linguagem é compreendida como prática discursiva, também é vista como a experiência de gerações, pois comunica a outros os conhecimentos, os valores, os sentidos, o modo de ser e de pensar dos sujeitos sociais.

Com efeito, o intuito é revisitar as teorias acerca dos letramentos e suas ramificações, sob a óptica da TA, da ADD e dos NEL. Parte-se, inicialmente, da concepção acerca das práticas de linguagem na vida humana, com enfoque nos preceitos da psicopedagogia e da filosofia da linguagem, para compreender os processos de letramentos como formas de interação e de cultura. Entendem-se essas ações, situadas histórica e culturalmente, como vivências em construção e reconstrução, propiciando os saberes sociais. Ao associar os estudos linguísticos à concepção de método do materialismo histórico dialético, constrói-se a possibilidade de reflexão sobre vários conceitos didáticos e metodológicos que englobam o processo de ensino e de aprendizagem.

A Teoria Histórico-Cultural da Atividade ou Teoria da Atividade - TA corresponde a um paradigma teórico-metodológico que focaliza o estudo das variadas práticas humanas como processo coletivo e individual. Analisa o desenvolvimento da consciência, com foco nos impactos psicológicos da atividade organizada, nas condições e nos sistemas sociais produzidos em e por tal atividade, pragmaticamente (HEEMANN, 2010; DANIELS, 2003). É respaldada em expoentes teóricos da Psicologia na Educação da Escola Russa, principalmente nos estudos de Vigotski (2001 [1934]), Leontiev (2004), Luria (1977), Rubinstein (1977) e Davidov (1988).

Para a perspectiva teórica, os homens modificam da natureza em função do desenvolvimento das suas necessidades (LEONTIEV, 2004). Criam os objetos e seus meios de produção, dos instrumentos às máquinas mais complexas. Assim, desenvolve-se também a cultura, pois o conhecimento do mundo circundante e do próprio homem se enriquece, surgindo a ciência e a arte.

Em todo o progresso no desenvolvimento do trabalho, marca-se um novo grau no aprimoramento das aptidões motoras do homem. Cada geração inicia sua vida em um mundo de objetos e de fenômenos criados pelas gerações precedentes, apropriando-se das suas riquezas - participam do trabalho, da produção e das diversas formas de atividade social -, e expandindo as aptidões especificamente humanas. Mesmo a aptidão para usar a linguagem articulada só se forma, em cada geração, pela aprendizagem da língua, que se desenvolve em um processo histórico social (LEONTIEV, 2004). 
O mesmo se passa com o desenvolvimento do pensamento ou da aquisição do saber, pois depende da apropriação dos resultados da atividade cognitiva de outras gerações. Entende-se que as aptidões e os caracteres especificamente humanos não se transmitem de modo algum por hereditariedade biológica, mas são apreendidos no decurso da vida, por um processo de apropriação da cultura criada pelos antecessores (VOLOCHÍNOV, 2013).

As relações que o homem tem com o que o cerca - suas percepções sensoriais, seus sentimentos, sua postura comportamental, suas ações -, determinam-no como sujeito social, bem como definem a sua forma de se apropriar da realidade humana (MARX, 2008). Esse processo resulta em cosmovisões e mundividências que são sempre ativas. Ao se apropriar de objetos ou de fenômenos, desenvolve-se uma atividade representativa do original, resultando em um conhecimento cumulativo. O instrumento não é apenas um objeto, mas um produto de uma cultura material que leva em si os traços característicos da criação humana. É um objeto social. Esse fato está cristalizado nos instrumentos humanos, distinguindo-os dos outros animais (LEONTIEV, 2004).

Para as outras espécies, não há geração, a partir do uso de instrumentos, de novas formações motoras, pois se subordinam aos movimentos instintivos, primários. Nos homens, as mãos, instrumento adâmico de trabalho, integram o sistema sóciohistoricamente elaborado das operações incorporadas em outros instrumentos que a elas subordinam-se. Assim, associar um instrumento corresponde, no viés humano, a desenvolver as operações motoras em seu potencial (LEONTIEV, 2004).

Formam-se, concomitantemente, novas aptidões, impulsionando funções superiores, psicomotoras, que hominizam ${ }^{12}$ sua força de vida. O homem, portanto, fisicamente, nasce humano, mas, quanto aos caracteres psíquicos, precisa apropriar-se das potencialidades que estão na sociedade. Assim, só se humaniza no convívio social (LURIA, 1977).

Logo, viver em grupo e liberar a atividade de preensão das mãos correspondem a ações que preparam o indivíduo para o surgimento do trabalho, processo que liga o homem à natureza. Para desenvolver os instrumentos necessários à execução dessa atividade, altera-se o estado natural do objeto e essa alteração é passada a gerações posteriores, afetando a todos.

Esses atos exigem consciência, derivando o pensamento, porque, quando se fabrica algum instrumento, fabrica-o para uma determinada finalidade. Há o surgimento da reflexão ${ }^{13}$. Essa consciência, por sua vez, só se desenvolverá na relação do homem com o trabalho, pois o pensamento é o reflexo consciente da realidade.

\footnotetext{
${ }^{12}$ Hominização significa tornar o homem um ser que se humaniza em contato com a sociedade. Para se inserir na vida em sociedade, deve apreender a articulação estável dos fenômenos por meio da linguagem, na consciência social materializada (MÁRKUS, 1974).

${ }^{13}$ Deve-se entender reflexão como um ato de conscientização no homem, que percebe e analisa a sociedade em que vive, por meio das relações sociais (FREIRE, 2003).
} 
Para explicar a apropriação linguística, Leontiev argumenta que o processo de desenvolvimento evolutivo na Pré-história apresenta três etapas: na primeira, ocorre a observação - os movimentos indicam o que está sendo feito e aqueles que não os visualizam não aprendem; na segunda, materializa-se o gesto acompanhado de sons; e, na terceira, apresenta-se a fala - um indivíduo emite um som e aponta para o objeto, o outro repete o mesmo som e o objeto passa a ter um nome (LEONTIEV, 2004). O sistema de códigos linguísticos, com efeito, permite ao homem o processo mnemônico: mantém os objetos na memória, origina imagens interiores e as categoriza.

A linguagem, consequentemente, forma, organiza e comunica o pensamento. Tratase de um sistema simbólico que se origina por meio da inevitabilidade de se estabelecer relações no trabalho, atividade tipicamente humana (VIGOTSKI, 2001 [1934]). Vista dessa perspectiva, entende-se a linguagem como histórica, resultado da atividade mental dos sujeitos sociais, em função da interação comunicativa, da construção do conhecimento e da resolução de problemas. Logo, sendo uma atividade mental humana, caracteriza-se como um processo pessoal e social ao mesmo tempo.

Por conseguinte, nas interações, há o modo de perceber e de organizar o mundo. A linguagem é que medeia essas relações sociais. O desenvolvimento mental, portanto, depende da linguagem, uma vez que o pensamento e a palavra se articulam e essa articulação só se efetiva nas situações sociais (BAKHTIN, 2003 [1979]; VIGOTSKI, 2001[1934]).

Assim, o processo de ensino e de aprendizagem de um indivíduo depende muito das possibilidades de que dispõe nas suas relações, de se aproximar do conhecimento históricocultural desenvolvido e materializado nas palavras. A apropriação da linguagem demanda um processo de compreensão linguística arraigado na história, formando as funções de articulação e de audição da palavra no homem.

Isso demonstra que a construção do conhecimento ocorre a partir de um intenso processo de interação social e que o ser, por meio da relação com outras pessoas, evolui de formas elementares para formas mais abstratas, o que o ajuda a conhecer e a controlar a realidade. São as intervenções deliberadas das pessoas que tornam possível ao sujeito a apropriação de unidades significativas da língua e, consequentemente, a caracterização do pensamento consciente.

Sob a óptica da ADD, é por meio da interação verbal que a palavra efetiva-se, caracterizando-se como signo ideológico. Dialética e plurissignificativamente, insere-se em um contexto sócio-histórico-cultural (BAKHTIN, 2003 [1979]). Dessa maneira, constituído pelo fenômeno da interação social, o diálogo revela-se como a tessitura da vida pela linguagem (KRAEMER, 2014b).

Sistematizando o conhecimento na interação, em um processo dialético constante, os pensamentos e as atividades humanas propagam-se no e pelo discurso, enunciando-os concretamente. Os grupos sociais, cronotopicamente, apresentam um conjunto de formas de discurso que funciona como um espelho do cotidiano. A palavra é a imagem desse espaço no 
qual os valores fundamentais de uma dada sociedade explicitam-se e confrontam-se (BAKHTIN/VOLOCHÍNOV, 2006 [1929]). Como é na e pelas práticas sociais que o homem se constitui como ser humano, desenvolvendo a linguagem e construindo sua identidade, o eu será sempre produto de interações sociais e da apropriação dos discursos alheios (MAGALHÃES, 2009).

Logo, o outro é importante não só no processo de construção do conhecimento, como também na constituição do próprio sujeito e de suas formas de agir. A mediação, com efeito, torna-se um dos aspectos fundamentais para qualquer aprendizagem. Isso porque uma operação representa inicialmente uma atividade externa, a qual é reconstruída e começa a ocorrer internamente. Segundo Vigotski, desenvolve-se, nesse processo de transformação, a inteligência prática, a atenção voluntária e a memória (VIGOTSKI, 2001 [1934]).

Um processo interpessoal é transformado em intrapessoal, sempre mediado pelo signo, uma vez que todas as funções no desenvolvimento da cognoscitividade acontecem simultaneamente: no nível social e no nível individual; entre pessoas, interpsicologicamente, e no interior do indivíduo, intrapsicologicamente. Essa transformação é o resultado de uma longa série de eventos ocorridos ao longo do desenvolvimento, o qual "[...] se dá não em círculo, mas em espiral, passando por um mesmo ponto a cada nova revolução, enquanto avança para um nível superior." (VIGOTSKI, 2001 [1934], p.63).

É desse contexto que surge o conceito de dialogia. Na perspectiva sociológica da linguagem, o diálogo permite a troca de experiências entre as pessoas, entre as gerações, estabelecendo a interação com o outro, pelo fato de os homens compartilharem conhecimentos, valores, sentidos, seu modo de ser e de pensar.

A linguagem pressupõe um processo de compreensão responsiva, de acordo com a necessidade de interação dos sujeitos nas diferentes esferas de atividades humanas. Por isso, Bakhtin considera que toda compreensão do enunciado é de natureza responsiva, "[...] toda compreensão é prenhe de resposta, e nessa ou naquela forma a gera obrigatoriamente: o ouvinte se torna falante." (BAKHTIN, 2003 [1979], p.271).

Essa orientação da palavra em função de outro é precípua para a concepção de linguagem como interação, entendendo-a como um fenômeno multifacético, uma vez que é determinada tanto por proceder de alguém, como por se dirigir a alguém. Constitui justamente o produto da interação do enunciador e do coenunciador. A enunciação, portanto, é um resultado da interação social, quer se trate de um ato de fala determinado pela situação imediata ou pelo contexto mais amplo, mediato, que constitui o conjunto das condições de vida de uma determinada comunidade linguística.

Ao direcionar a natureza social e dialógica constitutiva da linguagem, a epistemologia desse âmbito do saber encaminha para um conceito de ensino e de aprendizagem em que o dialogismo torna-se fundamento, por ser o elo entre os discursos dos participantes da interação, assimétrico e multidiversificado em sua natureza (MAGALHÃES, 2009). 
Logo, em se tratando de formação de professores, de ensino e de aprendizagem, o diálogo permanente e a desarmonia própria da interatividade são propícios, uma vez que levam a situações contextuais em que a dialética entre os paradigmas do senso comum e do conhecimento científico torna-se construtiva (MAGALHÃES, 2009; VIGOSTSKI, 2001; GASPARIN, 2007). Isso porque o processo, ao mesmo tempo, reflete os conhecimentos internalizados e a apropriação de novas significações.

Nesse embate contínuo, consoante Magalhães, entender o processo das ações da linguagem é imprescindível, porque é desse contexto que emerge a identidade do sujeito (MAGALHÃES, 2009). Para que a formação seja efetivamente crítica, defende-se o estabelecimento de práticas pertinentes em relação às ações de linguagem nos contextos educacionais, em que a complexa rede entre teoria e prática seja evidenciada, com uma visão de alteridade sobre a produção, a recepção e o entorno a que se destina o conteúdo trabalhado.

Inserem-se, nessa situacionalidade, as comunidades de prática, consideradas organismos vivos, criadas ao longo do tempo por meio da contínua busca de seus membros por objetivos comuns. De acordo com Wenger, o ser social é comprometido com suas metas, as quais se inserem em distintos contextos: “À medida que o tempo passa, essa aprendizagem coletiva resulta em práticas que refletem tanto a busca de nossos objetivos quanto as relações sociais concomitantes. Essas práticas são, portanto, propriedade de um tipo de comunidade [...] as comunidades de prática." (WENGER, 1998, p. 45).

O sujeito, ao desenvolver capacidades criadas na história social, aprimora suas funções psíquicas em meio a comunidades organizadas (LEONTIEV, 2004; LURIA, 1977; VIGOTSKI, 2001 [1934]). Ele transforma a natureza, a partir do trabalho, produzindo conhecimentos e compartilhando-os em comunidades de prática, as quais se ampliam e se renovam, formando novos membros, que são orientados e apreendem a participar efetivamente das atividades desse grupo social (HANKS, 1991).

Nesse processo, o papel da linguagem é fundamental, uma vez que as ações verbais medeiam e constituem a interação social. Compreender essa dinâmica permite identificar marcas contextualizadoras da situação de produção, do horizonte social e da apreciação valorativa no tocante ao ato comunicativo (BAKHTIN, 2003 [1979]). A academia, nessa perspectiva, é uma comunidade de prática de produção de conhecimento, comprometida com a aprendizagem coletiva:

No processo histórico, essa aprendizagem coletiva produz práticas que reiteram os objetivos iniciais, bem como as necessidades decorrentes das relações sociais inseridas nesse contexto. A ampliação de uma comunidade de prática relaciona-se ao constante dinamismo do processo que se renova na formação de novos participantes sociais, os quais interagem no grupo e apreendem com os seus parceiros as atividades ali desenvolvidas (KRAEMER, 2014a, p. 95-96). 
Logo, o convívio social é condição precípua à apreensão do conhecimento, seja de maneira teórica ou empírica, uma vez que os participantes seniores, ao mediarem os saberes, possibilitam a apropriação dos estudos das gerações precedentes e a perenidade comunitária. No viés delimitado, define-se prática como um conjunto de formas de atividades convencionadas socialmente em um campo específico de ação humana.

Para participar de uma comunidade de prática, é necessário ser letrado nas atividades que tecem essa rede de relações. Logo, não é somente ler e escrever, mas realizar associações e interações com o que se lê e o que se escreve em ambiente interdiscursivo. No espaço acadêmico, o letramento significa o envolvimento de múltiplas capacidades de leitura e de escrita, na intensa compreensão de vínculos sociodiscursivos e interdiscursivos:

Cada vez que se senta para escrever para nós, o aluno tem que inventar a universidade para aquela circunstância - inventar a universidade, ou seja, uma ramificação dela, como História, Economia, Antropologia ou Inglês. Ele tem que aprender a falar nossa linguagem, falar como falamos, experimentar formas específicas de saber, selecionar, avaliar, relatar, concluir e argumentar que definem o discurso de nossa comunidade (BARTHOLOMAE, 1985, p. 273).

As práticas linguísticas exigem a articulação de vários fundamentos sociais que se constituem por meio de enunciados relativamente estáveis (FAIRCLOUGH, 2012), pois

[...] há atividades, sujeitos e suas relações sociais, instrumentos, objetos, tempo e lugar, forma de consciência, valores e discurso. Esses elementos que se interligam por meio de métodos próprios, dialeticamente, ao serem compartilhados no grupo, propiciam um padrão que fundamenta e atribui sentido às ações dos participantes em relação às necessidades específicas de cada esfera de atividade (KRAEMER, 2014a, p. 96).

Dessa forma, para a inserção na comunidade de prática acadêmica, o aluno "[...] precisa atuar em campos cujas normas reguladoras da apresentação de exemplos ou do desenvolvimento de uma argumentação são até mesmo para o profissional, ao mesmo tempo distintas e misteriosas." (BARTHOLOMAE, 1985, p. 273). Faz-se necessário o envolvimento e a completa interação, não só com materiais, mas também com os métodos de ensino e de aprendizagem.

No caso dos acadêmicos, de acordo com o espaço de investigação e os sujeitos partícipes da pesquisa em foco, essas práticas devem ser direcionadas a sua inclusão na comunidade docente, visto que se trata de um curso de licenciatura. Nesse contexto, sob a perspectiva dos NEL, para que os estudantes estejam academicamente letrados, é necessário que se apropriem das convenções e das regras do ambiente universitário, participando e contribuindo para o capital cultural formador desse espaço. 
O papel do professor é fundamental, uma vez que deve mediar o processo de construção de identidade, possibilitando a interação em diferentes situações com as distintas práticas de letramento (KLEIMAN, 2006; STREET, 2003b). Cabe ao docente a elaboração de estratégias de ensino e de aprendizagem da língua na perspectiva das práticas sociais. Possibilitar eventos de letramento ${ }^{14}$ propicia o desenvolvimento das competências linguísticas, textuais e sociais necessárias para a imersão no mundo escolar e acadêmico. Esses eventos tornam-se maiores e mais intensos, gerando práticas de letramento, as quais refletem no indivíduo a busca por autonomia.

O termo letramento nasce a partir de construções ideológicas de vários pesquisadores. Dentre eles, no Brasil, é fundamental destacar as contribuições de Paulo Freire, que traz novos conceitos para o termo alfabetização, definindo-a como uma forma de ler o mundo. Freire defende uma visão pedagógica que transcende o ato de ler e de escrever. Enfatiza a educação capaz de formar indivíduos pensantes, críticos, cujo ideal é a libertação do sistema opressor que os cerca (FREIRE, 1980; 1987; 2003; 2017).

No âmbito internacional, tem-se a contribuição de Street, sob a óptica dos NEL, que defende o letramento autônomo ${ }^{15}$ para refletir sobre as práticas de ensino e de aprendizagem, de forma crítica e reflexiva, dialogando com a proposta freiriana (STREET, 2003b; 2006; 2012; 2014).

Também há os estudos de autores filiados ao The New London Group (1996), os quais consideram que os processos de leitura e de escrita são constituídos não só por recursos verbais como semióticos (visuais, auditivos e espaciais) (STREET, 2014; KLEIMAN, 2008; SOARES, 2003).

Para essas perspectivas, os letramentos são práticas específicas determinadas por um espaço determinado de tempo e um contexto de produção próprio. Logo, os processos de desenvolvimento de habilidades de leitura e de escrita são constantes em vista das

\footnotetext{
${ }^{14}$ Street, ao invés de utilizar somente o termo letramento no singular, utiliza letramentos, eventos de letramento e práticas de letramento, terminologias-chave dos Novos Estudos do Letramento (NEL). $\mathrm{O}$ evento de letramento "[...] ajuda a focalizar uma situação particular onde as coisas estão acontecendo [...]", como, por exemplo, a leitura de um livro por uma criança ou a sugestão de um professor para a leitura de uma obra, explorando a curiosidade do aluno (STREET, 2012, p. 75). Quanto às práticas de letramento, elas se evidenciam de forma mais global e abrangente, são mais amplas e englobam os eventos de letramento. Street evidencia que: "[...] o conceito de práticas de letramento é realmente uma tentativa de lidar com os eventos e com os padrões de atividades de letramento, mas para ligá-los a alguma coisa mais ampla da natureza cultural e social." (STREET, 2012, p. 76).

${ }^{15}$ Para Street, letramento autônomo pressupõe a prática restrita aos círculos escolar-acadêmicos, "[...] centrada no sujeito e nas capacidades de usar apenas o texto escrito." (STREET, 2014, p. 09). Revela-se reducionista, uma vez que, geralmente, percebe a escrita como um produto completo em si mesmo e descontextualizado. $O$ autor diferencia essa prática do modelo de letramento ideológico que preconiza a interação social entre os sujeitos do discurso e a sua participação ativa, eivada por mundividências e cosmovisões próprias da diversidade cultural e histórica inerentes à contemporaneidade.
} 
diferentes situações de produção de um enunciado: letra-se na escola, letra-se na academia e letra-se em outros ambientes reais ou virtuais, de forma continuada e dialógica (STREET, 2012; FERREIRA, 2014).

Percebe-se, com efeito, que não se trata de uma nova nomenclatura para o termo alfabetização, mas uma construção epistemológica que privilegia a formação intelectiva direcionada ao social, realizando-se em diversos ambientes, que não só o escolar. Nesse viés, Kleiman afirma que letramento pressupõe “[...] uma perspectiva social da escrita na esfera de atividades escolares [...] [, tendo] por foco [ações] vinculadas à prática em que a leitura e a escrita [...] [tornam-se] ferramentas para agir socialmente." (KLEIMAN, 2010, p. 380).

A partir do momento em que o professor em formação inicial é capaz de refletir sobre suas próprias práticas sociais "[...] podemos mover o estudo do letramento para longe de generalizações idealizadas sobre a natureza da Linguagem e do Letramento e na direção de entendimentos mais concretos das práticas letradas em contextos sociais reais." (STREET, 2014 , p. 19). Pode-se, em virtude disso, desenvolver sua autonomia na elaboração e na construção de práticas pedagógicas estruturadas nas diferentes esferas de ensino e de aprendizagem.

A partir desses estudos, surge também o conceito de multimodalidade, condizente às propostas da educação globalizada, pois se trata do "[...] modo como as pessoas fazem uso dos recursos de significações disponíveis em um dado momento." (BEVILAQUA, 2013, p. 106). Contempla, portanto, as diferentes formas de leitura e de escrita contemporâneas. Permite a maior abrangência das possibilidades e das criações de eventos nas práticas de letramentos.

O letramento acadêmico engloba um conjunto de ações, bem como o desenvolvimento e o aprimoramento de múltiplas capacidades: “[...] a aprendizagem no ensino superior implica a adaptação a novas formas de saber: novas maneiras de compreender, interpretar e organizar o conhecimento." (LEA; STREET, 1998, p. 157). Essas adaptações resultam na construção de inter-relações linguísticas e discursivas, bem como na internalização de novas experiências e práticas que o ambiente acadêmico pressupõe.

Percebendo a importância do letramento em todas as esferas sociais e culturais, bem como o compromisso de criar condições para letrar e ser letrado, o professor em formação inicial deve ter consciência das práticas que o ambiente acadêmico prevê. De acordo com Street, "As práticas de letramento referem-se a essa concepção cultural mais ampla de modos particulares de pensar sobre a leitura e a escrita e de realizá-las em contextos culturais." (STREET, 2012, p.77).

Neste estudo, como se investigam os processos de letramento, bem como a construção e a inserção dos acadêmicos na comunidade de prática docente, "[...] é necessário analisar as relações sociais e a própria academia." (KRAEMER, 2014a, p. 97). Sendo assim, examina-se em que medida os acadêmicos do Curso em Letras estão se 
inserindo na comunidade docente e quais as concepções e as práticas de letramento que permeiam a formação inicial dos licenciados.

Sabe-se que, "[...] as práticas de letramento variam com o contexto cultural, não há um letramento autônomo, monolítico, único, cujas consequências para indivíduos e sociedades possam ser inferidas como resultados de suas características intrínsecas." (STREET, 2012, p. 82). Assim, deve-se atentar para o fato de que os acadêmicos, docentes em formação, precisam ser orientados e preparados reflexivamente para que, quando atuantes, criem eventos e práticas de letramentos necessários as suas ações professorais.

\section{Análise e Interpretação das Práticas de Letramento Acadêmico/Científico nas Fases Finais do Curso em Letras da UFFS}

Pretende-se, neste momento, traçar o percurso metodológico da pesquisa, para esclarecer o método analítico-interpretativo relacionado ao estudo das informações geradas. Como o pressuposto inicial da problematização investigativa estuda as concepções de letramento acadêmico-científico e seus desdobramentos na formação inicial de professores em língua materna do Curso em Letras da UFFS, Campus Realeza, opta-se por

Uma abordagem analítica na qual as práticas discursivas figuram como os elementos mais importantes para a construção de relações sociais e de conhecimentos em sala de aula [, determinando] a adoção de referenciais teóricos que considerem que essas realidades podem ser criadas na interação. Não é apenas o conteúdo temático o que será objeto da análise, mas a própria linguagem (KLEIMAN, 2008, p. 22).

A pesquisa, em vista disso, caracteriza-se por ser de natureza teórico-empírica, com caráter etnográfico, ao realizar um estudo de caso acerca de professores em formação inicial no ambiente acadêmico da Universidade, a fim de explicar o fenômeno investigado:

O recorte etnográfico, para fins de geração de dados, visa a compreender, no cotidiano da prática docente, o processo de ensino e de aprendizagem, aplicando métodos e técnicas compatíveis com a perspectiva qualitativointerpretativa. Pelo fato de essa maneira de analisar os fenômenos naturais estar associada à ideia de que o indivíduo é o elemento fundamental da atividade docente, [propõe-se] interpretar, [explorar] predominantemente materiais gerados qualitativamente, uma vez que o processo de localização e de produção [...] pressupõe a investigação de aspectos sociologicamente construídos, diferenciando-se em muitos pontos da postura que caracteriza o viés quantitativo (KRAEMER, 2014b, p. 59). 
Contudo, embora a abordagem dos dados seja, primordialmente, qualitativointerpretativa, uma vez que se propõe a elucidar em que medida os acadêmicos das fases finais do Curso em Letras da UFFS apresentam participação periférica legítima como aprendizes, a mensuração acontece também pelo meio quantitativo, no intuito de construir o cenário problematizador da pesquisa, utilizando o método de procedimento estatístico para quantificar as informações.

Nesse viés, a fundamentação teórica é construída por meio de documentação indireta: em referenciais bibliográficos - na triangulação de literatura pertinente à TA, à ADD e aos NEL, sob a óptica da LA; e fontes documentais do Curso em Letras da UFFS, como o Projeto Pedagógico do Curso de Graduação em Letras, Português e Espanhol, Licenciatura, bem como a Ementa, dados de cadastramento e estimativas da Secretária Acadêmica da Instituição, dentre outros aportes técnicos que subsidiam a pesquisa.

Quanto à análise e à interpretação dos dados, o método principal de abordagem é o hipotético-dedutivo, o qual parte de um problema da realidade concreta (1); busca, nas conjecturas pertinentes às teorias analisadas, deduções de proposições passíveis de serem testadas (2); e, por fim, realiza testes de falseamento, na tentativa de refutar ou aprovar a hipótese aventada no início do processo, até mesmo com a possibilidade de relativização da tese (LAKATOS; MARCONI, 2003, p. 95).

Além do método principal, trabalha-se com procedimentos técnicos secundários como o: estatístico, para mensurar os dados advindos do questionário proposto aos acadêmicos na documentação direta, construindo um cenário passível de problematização; o histórico e o comparativo, por meio da triangulação teórica da literatura especializada; monográfico, por se tratar de um estudo de caso, que é um recorte do microcosmo social no âmbito da educação de Ensino Superior (LAKATOS; MARCONI, 2003; KRAEMER, 2014b).

Dessa forma, a pretensão é a de verificar se os acadêmicos das fases finais do Curso em Letras da UFFS apresentam participação periférica legítima como aprendizes, uma vez que o estudante, nessa etapa educacional, “[...] desenvolve capacidades relativas ao letramento acadêmico/científico em atividades concretas mediadas por especialistas em sua comunidade de prática, em que as responsabilidades em relação à produção linguística são gradativamente progressivas, expandindo-se ao longo do percurso [...]" (KRAEMER, 2014a, p. 18).

A geração dos dados é realizada por meio da aplicação de um questionário disponibilizado na plataforma online Google Forms, em que cada participante, após a apresentação da pesquisa, é convidado a responder. Anterior à participação, os acadêmicos são orientados quanto aos procedimentos e às precauções recomendados pelo Comitê de Ética da UFSS (CEP) ${ }^{16}$, concordando e tendo ciência ao assinarem o Termo de Consentimento Livre e Esclarecido.

\footnotetext{
${ }^{16}$ Certificado de Apresentação para Apreciação Ética, CAAE n. 82379918.3.0000.5564 (BRASIL, 2018).
} 
Dentre os questionários aplicados aos acadêmicos, as primeiras perguntas visam a traçar um perfil social e econômico do público alvo - discentes que cursam as fases finais do Curso em Letras da UFFS. Assim, por meio das respostas, torna-se possível uma análise mais próxima da realidade vivenciada na Instituição de Ensino Superior. Também, pode-se perceber a proximidade dos acadêmicos com o mundo da leitura e da escrita, além de outras características referentes ao comportamento letrado desses sujeitos.

Além do questionário dirigido aos acadêmicos, cinco professores efetivos do Curso, que atuam com o ensino de língua portuguesa e de literaturas, são entrevistados. A estratégia de pesquisa usada é a de indagar sobre questões específicas ao ensino e à aprendizagem na Universidade, no que tange ao Curso em foco, bem como aos documentos oficiais regentes da matriz curricular, além de questionar acerca da relação dos acadêmicos com a comunidade de prática docente.

Assim, nesta pesquisa, faz-se relevante a análise concomitante das concepções sobre as práticas de letramento, refletidas na óptica docente e discente, tendo, como fio condutor da pesquisa, tanto o processo de ensino e de aprendizagem quanto a reflexão acerca de como se mostra a inserção dos acadêmicos em sua comunidade de prática. Para tornar mais claro o percurso de geração dos dados, apresentam-se, no Quadro 1, as perguntas propostas aos acadêmicos, com foco na aprendizagem:

Quadro 1: Questionário aos Acadêmicos do Curso em Letras

\begin{tabular}{|c|c|}
\hline \multicolumn{2}{|c|}{ QUESTIONÁRIO AOS ACADÊMICOS DO CURSO EM LETRAS - UFFS } \\
\hline Perfil Socioeconômico & Perfil Referente ao Letramento Acadêmico/Científico \\
\hline 1 Fase que está cursando: & $\begin{array}{l}14 \text { Participa de Projeto de ensino ou de pesquisa como } \\
\text { bolsista ou voluntário? }\end{array}$ \\
\hline 2 Faixa etária: & $\begin{array}{l}15 \text { Participa de Projeto de extensão como bolsista ou } \\
\text { voluntário? }\end{array}$ \\
\hline 3 Tipo de Ensino Médio cursado: & $\begin{array}{l}16 \text { Apresentou comunicação oral e/ou submeteu trabalho } \\
\text { acadêmico para publicação em periódico ou anais de } \\
\text { evento? }\end{array}$ \\
\hline 4 Ano de ingresso no Curso em Letras da UFFS: & $\begin{array}{l}17 \text { Há interesse e disponibilidade (carga horária) para } \\
\text { participar de projeto de pesquisa e/ou de extensão } \\
\text { e/ou de cultura? }\end{array}$ \\
\hline $\begin{array}{l}5 \text { Antes de ingressar no Curso em Letras da UFFS } \\
\text { residia em (informar Cidade e UF)? }\end{array}$ & 18 Em qual área há concentração de seus estudos? \\
\hline $\begin{array}{l}6 \text { Em caso de estar inserido(a) no mercado de } \\
\text { trabalho, qual seu vínculo e carga horária } \\
\text { (contrato temporário, CLT ou estágio não } \\
\text { obrigatório remunerado)? }\end{array}$ & $\begin{array}{l}19 \text { Avalie os métodos didático-pedagógicos docentes do } \\
\text { Curso em Letras da UFFS: }\end{array}$ \\
\hline $\begin{array}{l}7 \text { Cursou outra faculdade, anterior ao Curso em } \\
\text { Letras da UFFS? }\end{array}$ & $\begin{array}{l}20 \text { Ser letrado para as práticas sociais corresponde ao } \\
\text { "[...] estado que assume aquele que, além de aprender } \\
\text { a ler e a escrever, é capaz de realizar associações e } \\
\text { interações com o que lê e o que escreve, em sua }\end{array}$ \\
\hline
\end{tabular}




\begin{tabular}{|c|c|}
\hline & $\begin{array}{l}\text { comunidade de prática e seu ambiente } \\
\text { interdiscursivo." (KLEIMAN. 2006, p. 16). Diante disso, } \\
\text { como se tem apresentado sua experiência com } \\
\text { letramento acadêmico/científico durante o Curso em } \\
\text { Letras? }\end{array}$ \\
\hline $\begin{array}{l}8 \text { Cursa outra faculdade concomitante ao Curso } \\
\text { em Letras da UFFS? }\end{array}$ & $\begin{array}{l}21 \text { Em que medida julga importante para o profissional de } \\
\text { Letras o domínio da leitura e da escrita às práticas } \\
\text { sociais em sua comunidade educacional? }\end{array}$ \\
\hline $\begin{array}{l}9 \text { Descreva o fator determinante para a escolha do } \\
\text { Curso em Letras da UFFS: }\end{array}$ & $\begin{array}{l}22 \text { Qual é sua proficiência de aprendizagem em relação } \\
\text { aos métodos de ensino nos diferentes Componentes } \\
\text { Curriculares do Curso de Letras da UFFS, no que tange } \\
\text { aos processos de leitura e de escrita? Justifique sua } \\
\text { resposta. }\end{array}$ \\
\hline $\begin{array}{l}10 \text { Explicite seu grau de expectativa quanto ao } \\
\text { Curso em Letras da UFFS: }\end{array}$ & $\begin{array}{l}23 \text { Descreva os gêneros discursivos mais trabalhados no } \\
\text { Curso em Letras no que tange ao desenvolvimento do } \\
\text { letramento acadêmico/científico do discente e } \\
\text { comente as possíveis razões para essas escolhas? }\end{array}$ \\
\hline $\begin{array}{l}11 \text { Já teve acesso ao Projeto Pedagógico do Curso } \\
\text { de Graduação em Letras, Português e } \\
\text { Espanhol, Licenciatura (PPC) da UFFS e realizou } \\
\text { sua leitura? }\end{array}$ & $\begin{array}{l}24 \text { Ao compreender "comunidade de prática" como "[...] } \\
\text { um grupo de pessoas que compartilha um objetivo, } \\
\text { interesse ou necessidade comum e se engaja em um } \\
\text { processo de aprendizagem coletiva [...]" (LAVE; } \\
\text { WENGER, 1991). Comente os pontos favoráveis e os } \\
\text { enfrentamentos em sua inserção na comunidade de } \\
\text { prática docente? Justifique sua resposta. }\end{array}$ \\
\hline 12 Recebe algum tipo de bolsa e/ou auxílio PIBID? & $\begin{array}{l}25 \text { Há estratégias explícitas ou implícitas na prática } \\
\text { pedagógica dos professores para que os acadêmicos } \\
\text { do Curso de Letras insiram-se apropriadamente em } \\
\text { uma comunidade de prática docente? Justifique sua } \\
\text { resposta. }\end{array}$ \\
\hline $\begin{array}{l}13 \text { Faz uso dos livros e periódicos disponibilizados } \\
\text { pela Biblioteca da UFFS? }\end{array}$ & $\begin{array}{l}26 \text { Reconhece-se como professor em formação inicial? } \\
\text { Descreva os pontos positivos da sua inserção no } \\
\text { ambiente acadêmico de licenciatura e o que pode ser } \\
\text { aspecto de melhoria? }\end{array}$ \\
\hline
\end{tabular}

Fonte: Produção das Pesquisadoras

Neste estudo, são ressaltadas as informações mais relevantes à pesquisa. Opta-se pelas questões consideradas mais influentes nos resultados e na construção da resposta à hipótese de pesquisa. Ressalta-se que as questões socioeconômicas são importantes para a construção do perfil dos discentes partícipes da pesquisa, bem como para a produção do cenário de análise. Possibilitam a percepção mais clara do objetivo principal do estudo, com foco na aprendizagem, que é entender os processos de letramento acadêmico-científico e como acontece a inserção dos acadêmicos na comunidade de prática. No Quadro 2, da mesma forma, as questões destinadas aos docentes propõem-se a auxiliar na distinção desse panorama, mas com atenção ao ensino: 
Quadro 2: Questionário aos Docentes do Curso em Letras

\section{QUESTIONÁRIO AOS DOCENTES DO CURSO EM LETRAS}

1- De acordo com o Projeto Político Pedagógico (PPC) do Curso em Letras, Português e Espanhol, Licenciatura, da UFFS, a leitura é uma atividade formativa e transformadora das atividades sociais e culturais. Como esse processo de leitura se apresenta entre os acadêmicos?

2- No que se refere a leituras teóricas, em que medida os acadêmicos participam integralmente do processo de construção de sentidos?

3- O PPC propõe a reflexão sobre a materialidade significativa dos eixos estruturantes do Curso. Em que medida os acadêmicos mostram-se reflexivos em atividades de leitura e de escrita, a fim de construir um posicionamento perante as teorias estudadas?

4- Os acadêmicos das fases finais, em sua maioria, atendem à proposta do Curso quanto à proficiência de leitura e de escrita? Justifique.

5- Qual o perfil pretendido dos professores em formação do Curso em Letras e qual tem sido o alcance dessa meta?

6- Ao entender comunidade de prática como "[...] um grupo de pessoas que compartilha um objetivo, interesse ou necessidade comum e se engaja em um processo de aprendizagem coletiva [...]" (LAVE; WENGER, 1991), em que medida os acadêmicos apresentam aptidão a integrarem-se nesse ambiente docente?

7 Ser letrado para as práticas sociais corresponde ao "[...] estado que assume aquele que, além de aprender a ler e a escrever, é capaz de realizar associações e interações com o que lê e o que escreve, em sua comunidade de prática e seu ambiente interdiscursivo." (KLEIMAN, 2006, p. 16). No que tange ao âmbito acadêmico/científico, qual o papel dos atores desse processo (os acadêmicos) no Curso em Letras, bem como os seus desafios?

8- Existem estratégias sistematizadas pelo Curso em Letras para que se viabilize o letramento acadêmico/científico, possibilitando ao discente inserir-se com proficiência em uma comunidade de prática docente?

Fonte: Produção das Pesquisadoras

O processo de geração e o percurso analítico dos dados acontecem de acordo com as informações fornecidas pela Secretária Acadêmica de Curso, considerando os acadêmicos que estão matriculados nas últimas fases da Graduação em Letras, Português e Espanhol. O recorte de dados/informações estabelecido é de 37 alunos, sendo que todos acordam que têm possibilidade de acessar o espaço virtual em que são convidados a responder o questionário, porém, somente 23 alunos participam da pesquisa, cumprindo com todas suas etapas. É percebido que, desses 23 acadêmicos, 54,05\% estão cursando a 9 Fase e 40,09 \%, a 70 Fase. 0 restante alterna-se em ambas ${ }^{17}$.

O perfil discente, que contempla essa etapa do Curso, é composto de acadêmicos entre 19 e 45 anos de idade, em que 18,2\% têm o diploma de Magistério; 9,1\%,m Ensino Médio Técnico; e 68,2\%, o Ensino Médio Regular. Esses índices revelam também que os formados em Magistério fazem parte da 9o Fase e já possuem experiências com o ambiente docente.

\footnotetext{
${ }^{17}$ Alguns alunos cursam diferentes fases, em período concomitante. Nestes casos, considera-se, para fins de recorte, quem têm cumprido a maior parte dos créditos.
} 
Os dados gerados permitem visualizar um panorama diferenciado à análise da pesquisa, pois o maior número de acadêmicos da 9 o Fase participa de eventos de letramento desde o Ensino Médio. Isso pode ser considerado como uma contribuição a sua formação, não só para os processos de letramento, mas também para a inserção proficiente em comunidades de prática docente, visto que se envolvem em ações professorais direcionadas ao trabalho com a educação infantil e, posteriormente, na licenciatura, apropriam-se de conhecimentos que possibilitam desenvolver capacidades de ações docentes no ambiente do Ensino Fundamental e do Ensino Médio.

É possível que, neste caso, ao iniciarem a graduação com noção preliminar do que sejam os processos de ensino e de aprendizagem, estabeleça-se um ambiente mais confortável a esses acadêmicos para apreenderem novos conhecimentos pedagógicos e linguísticos, em contraposição aos $68,2 \%$ que têm contato com esses processos específicos somente no Ensino Superior. Outro aspecto identificado relaciona-se às cidades em que os estudantes investigados residem - circunvizinhas à UFFS, Campus Realeza, compartilhando de perfil econômico, social e cultural semelhante -, e o período de trabalho, na maioria, entre 20 e 44 horas.

Essas informações conduzem a inferências acerca da importância entre os elos de língua, sociedade e cultura, bem como a relação diacrônica e espacial entre eles (SOARES, 2003). É por meio desse entrelace da perspectiva social que a língua, a escrita e a cultura têm influência nos eventos de letramento vivenciados pelos acadêmicos, pois $54,5 \%$ optam pelo curso em licenciatura por se tratar de uma graduação em universidade pública, localizada nas proximidades da região em que residem.

Também, revela o perfil profissional dos estudantes, que mantém mais contato, em função de seu trabalho e de sua vida privada, com o modelo de letramento autônomo, o qual pressupõe a prática restrita de letramento específico aos círculos acadêmicos, "[...] centrada no sujeito e nas capacidades de usar apenas o texto escrito." (STREET, 2014, p. 09). Nesse viés, os acadêmicos demonstram valorizar a ampliação de sua participação consciente em ações de ensino e de aprendizagem que desenvolvam o modelo de letramento ideológico (STREET, 2014) presentes, no contexto investigado, fundamentalmente, na práxis das licenciaturas e no desenvolvimento de programas e de projetos de ensino, de pesquisa e de extensão.

Os dados gerados mostram, nesse aspecto, que apenas $21,07 \%$ dos acadêmicos entrevistados participam atualmente de projetos de ensino ou de pesquisa e somente $13 \%$ são extensionistas. Embora 65,02\% dos acadêmicos demonstrem interesse nessas ações universitárias, a alegação da baixa participatividade está relacionada ao fato de muitos estarem no mercado de trabalho, com carga horária indisponível às atividades em contra turno.

Logo, mesmo que poucos acadêmicos tenham a oportunidade e a disponibilidade de participar de ações dessa natureza em função de sua rotina laboral, grande parte as 
reconhece como práticas positivas. Isso é significativo, uma vez que a conscientização acerca da importância de programas e de projetos extracurriculares, por potencializarem a inserção do acadêmico, tanto na comunidade interna como externa à Universidade, é um aspecto preponderante e salutar da vida discente.

Ao extrapolarem as atividades convencionais do Curso, participam de experiências diferenciadoras e que devem ser valorizadas. Nesse sentido, em um contexto otimista de políticas públicas, se houver mais incentivos universitários, do ponto de vista financeiro, é possível que um maior número de acadêmicos, futuramente, sinta-se favorável a participar efetivamente de programas e de projetos oferecidos pelas IES, direcionados à formação inicial docente.

Quando questionados sobre as dificuldades de aprendizagem em relação aos métodos de ensino nos diferentes componentes curriculares do Curso em Letras da UFFS, no que tange aos processos de leitura e de escrita, os estudantes expressam que os principais desafios encontrados estão no início da graduação. Alegam que o Ensino Médio não os prepara substancialmente para as questões teóricas propostas na universidade, como em relação às concepções de língua e de linguagem, além do estudo de gêneros discursivos. Ressaltam, no entanto, que, nas fases finais, a maioria já está adaptada ao Curso, desenvolvendo métodos de estudo sobre atividade de leitura e de escrita adequados, bem como de técnicas de aprendizagem pertinentes a essas capacidades.

Essa constatação também é explicitada por Motta-Roth, uma que vez que, na universidade, a grade de ensino é estruturada em componentes curriculares, os quais são sequenciados para a evolução das habilidades necessárias ao domínio da leitura e da escrita, como também para a inserção dos acadêmicos na comunidade de prática docente. Assim, "[...] podemos pensar que cada disciplina ou área do saber que compõe o universo acadêmico de pesquisa e ensino nas universidades corresponde a uma grande comunidade de prática, compreendida de unidades menores, organizadas em rede." (MOTTA-ROTH, 2013, p.137).

Contudo, uma parte dos discentes das últimas fases do Curso ainda sente dificuldades na proficiência da leitura e na compreensão de textos teóricos, justamente os que estão mais afastados dos programas e dos projetos dirigidos à prática inicial docente. Em consonância, os docentes percebem essas disparidades, ressaltando a importância de se identificar essas lacunas de conhecimento e estabelecer estratégias de ensino - como orientações extraclasses e estudos em projetos de monitoria ${ }^{18}$, que têm se efetivado na Instituição -, a fim de, por meio de ações de ensino, sanar dúvidas e dificuldades.

\footnotetext{
${ }^{18} \mathrm{Em}$ virtude da identificação dessas dificuldades, em 2018, é efetivado, na Instituição, entre outros, o projeto no âmbito do ensino, Leitura e Produção Textual: práticas de letramento acadêmicocientífico na monitoria da UFFS - Campus Realeza, coordenado pela Prof.e Dr.a Márcia Adriana Dias Kraemer, com o intuito de mediar o conhecimento acerca da leitura e da produção textual de gêneros acadêmico-científicos aos discentes interessados no aprimoramento dessas práticas (UNIVERSIDADE FEDERAL DA FRONTEIRA SUL, 2018).
} 
Em relação ao entendimento do que seja uma comunidade de prática, dos pontos favoráveis e dos enfrentamentos da inserção pessoal na sociedade específica do Curso em Letras, é percebido que os acadêmicos, mesmo os que apresentam dificuldades de proficiência plena, estão em processo de inserção e de participação na comunidade de prática docente, pois apresentam participação periférica legítima, por meio de sua atuação em diferentes atividades, integrando-se ao objetivo comum desse reduto social.

A principal forma de consolidação justificada, tanto pelos estudantes como pelos docentes, é o envolvimento com: a) o Programa Institucional de Bolsas de Iniciação à Docência - PIBID e o Programa Institucional de Bolsas de Iniciação Científica - PIBIC; b) os projetos de ensino, de extensão e de pesquisa oferecidos pelo Curso, cuja participação dos entrevistados é parcial; c) os Estágios Curriculares Supervisionados previstos no PPC do Curso, principalmente os de longa duração, em que todos estão vinculados.

Além disso, a pesquisa demonstra que 69,6\% dos participantes já apresentam convívio em eventos de letramento. Essas atividades são importantes para a construção tanto do letramento autônomo como do ideológico. Possibilita-lhes a inserção em sua comunidade de prática docente, a partir dos programas e dos projetos mencionados, bem como dos eventos científicos específicos da área do saber em que o Curso em Letras da UFFS inscreve-se.

Outra constatação é a de que a maior parte desse último percentual pertence à última fase do Curso, evidenciando que há, consequentemente, maior carga horária de estágios e maior nível de produção acadêmica, intensificados nos semestres finais. Com os estágios, aumentam as experiências e, por meio deles, os discentes constroem relatórios que, geralmente, são apresentados em eventos acadêmicos, bem como reorganizados para publicações em periódicos e anais científicos, com mediação de seus preceptores, partícipes mais experientes dessa comunidade de prática linguística.

Um aspecto relevante está na construção do projeto e do relatório de pesquisa na produção do Trabalho de Conclusão de Curso, que se pressupõe auxiliar fundamentalmente na geração de autonomia na escrita e na possibilidade do reconhecimento de autoria. Contudo, de acordo com Street, o letramento autônomo prevalente a círculos acadêmicos pode isolar o processo de aprendizagem, tornando essa prática restrita a modelos préestabelecidos, se não houver o privilégio de coaduná-lo às práticas sociais. Já o modelo ideológico preconiza os processos de leitura e de escrita, reconhecendo a natureza ideológica dessas práticas, parte de um contexto situado social, cultural e historicamente:

Se, por um lado, muitos educadores e idealizadores de políticas veem o letramento como sendo uma habilidade meramente neutra, igual em qualquer lugar e a ser distribuída (quase que injetada em alguns discursos baseados em ideias médicas) para todos em iguais medidas, o modelo ideológico reconhece que as decisões políticas e em educação precisam estar baseadas em julgamentos prévios sobre que letramento deve ser distribuído, e por quê. Assim sendo, a pesquisa de caráter etnográfico não 
sugere que as pessoas sejam simplesmente deixadas como estejam, com base no argumento relativista de que um tipo de letramento é tão bom quanto o outro. Mas também não sugere que as pessoas simplesmente devem "receber" o tipo de letramento formal e acadêmico conhecido pelos responsáveis pela determinação de políticas e que, de fato, muitas delas já terão rejeitado. "Fornecer" esse tipo de letramento formalizado não levará à atribuição de poder, não facilitará novos empregos e não gerará mobilidade social (STREET, 2003b, p. 10-11).

Nesse sentido, o Projeto Pedagógico do Curso de Graduação em Letras, Português e Espanhol, Licenciatura, da UFFS contempla, como a Matriz Curricular, três grandes áreas de ensino e de aprendizagem; o Domínio Comum, o Conexo e o Específico. No primeiro, pretende-se que o acadêmico apresente "[...] a consciência sobre as questões que dizem respeito ao convívio humano em sociedade, às relações de poder, às valorações sociais, à organização sócio-político-econômica e cultural das sociedades, nas suas várias dimensões." (UNIVERSIDADE FEDERAL DA FRONTEIRA SUL, 2010, p. 37).

Já o segundo, o Domínio Conexo, é composto pelo “[...] conjunto das disciplinas da área pedagógica, as quais têm por finalidade situar e habilitar o aluno do curso para a prática docente, seja para o ensino de língua materna e estrangeira, além das respectivas literaturas." (UNIVERSIDADE FEDERAL DA FRONTEIRA SUL, 2010, p. 37). Por fim, o Domínio Específico relaciona-se aos componentes curriculares ofertados no decorrer do Curso, contemplando a área de língua portuguesa, de língua espanhola e de suas literaturas.

Em consonância com essa proposta, os docentes indagados acreditam que os letramentos na Universidade ocorrem de forma gradual e processual, em detrimento das dificuldades advindas da educação básica, que se estende à universidade e às práticas estudantis. Para os professores, embora haja dificuldades na apropriação de conhecimentos atinentes ao campo linguístico, devido à complexidade inerente ao estudo científico, no decorrer do processo, os alunos, mediados pelos seus mentores, apresentam condições adequadas para o processo de aprendizagem e para o desenvolvimento das capacidades de leitura e de escrita às práticas sociais.

Assim, de forma orientada - conforme as palavras dos professores entrevistados, nas primeiras fases -, os alunos, gradativamente, conseguem inserir-se no ambiente acadêmico. Ocorre, paulatinamente, o desenvolvimento e a construção de sua autonomia para questões linguísticas de ensino e de aprendizagem ao longo do Curso. Nesse sentido, entendem que ser letrado para as práticas sociais corresponde ao "[...] estado que assume aquele que, além de aprender a ler e a escrever, é capaz de realizar associações e interações com o que lê e o que escreve, em sua comunidade de prática e seu ambiente interdiscursivo." (KLEIMAN. 2006, p. 16).

As vivências acadêmico-científicas tendem à construção dos letramentos para as práticas sociais, seja por intermédio de professores, pela relação entre os pares, ou pela participação em programas e projetos que essa comunidade de prática pressupõe (WENGER, 
1998). Nesse aspecto, os estudantes ressaltam, ainda, a importância de sua inserção no processo criativo e reflexivo que a comunidade de prática docente proporciona e as relações interpessoais que a contemplam.

Street define que as práticas de letramento são situadas nas relações sociais em que cada sujeito reflete sobre sua individualidade, construindo a identidade no comando dessas práticas (STREET, 2003b). Nesse sentido, todos os entrevistados, discentes e docentes, afirmam que há fundamental importância do domínio da leitura e da escrita na universidade para a inserção pertinente do professor em formação no ambiente escolar-acadêmico.

Infere-se que, com base nas considerações apontadas neste estudo, as práticas de letramentos são os modos de utilizar a leitura e a escrita para construir valores no contexto em que os sujeitos participam. Assim, os acadêmicos podem compartilhar dos mesmos eventos de letramento, mesmo que suas práticas caracterizem-se como subjetivas, produzindo sentidos diferentes em cada ação desse processo de construção e de aprimoramento das capacidades de leitura e de escrita.

\section{Considerações Finais}

Em resposta à pergunta de pesquisa proposta para este estudo, a hipótese de que os acadêmicos das fases finais do Curso em Letras da UFFS, partícipes da investigação, demonstram participação periférica legítima como aprendizes é corroborada pelo resultado da geração de dados e da análise empreendida. A partir de diferentes práticas, os universitários inserem-se na comunidade de prática docente e se reconhecem como professores em formação inicial.

Entende-se, também, em consonância com os instrumentos aplicados, que a legitimidade desse processo ocorre por meio da práxis, principalmente, como resultado: de programas que privilegiam a docência e de estágios curriculares supervisionados; de participação em atividades curriculares e extracurriculares de ensino, de pesquisa e de extensão. Essas ações colaboram fundamentalmente à apropriação dos conhecimentos linguístico-pedagógicos e à construção de saberes teórico-práticos nos componentes curriculares do Curso.

Por meio desta reflexão, entende-se que as práticas docentes dos professores em formação, em decorrência dos diferentes tipos de letramentos, contribuem à sua inserção em comunidade de prática específica. Ademais, os dados decorrentes da pesquisa, além de auxiliarem a criar um diagnóstico do Curso em foco, no que tange à aprendizagem de leitura e de escrita, oportunizam outras investigações de cunho etnográfico, nesse mesmo ambiente universitário. 
Acredita-se que o aprofundamento da temática e o estabelecimento de novas estratégias de intervenção nas práticas docentes dos professores em formação possibilitam alcançar a melhoria no aproveitamento das ações de letramentos. Esse pode ser um caminho possível para, dentro do contexto educacional, rivalizar com a fragmentação do ensino nas sociedades complexas. Desse modo, ressalta-se o valor de os professores em formação identificarem-se como autores de seu próprio discurso em seu ambiente formativo, refletindo acerca dos múltiplos letramentos necessários à construção do conhecimento desses profissionais da educação.

\section{Referências}

ADORNO, T. W. Indústria Cultural e Sociedade. Seleção de textos de Jorge Mattos Brito de Almeida. Tradução de Juba Elisabeth Levy et al. São Paulo: Paz e Terra, 2002.

BAKHTIN, M. M.; VOLOCHÍNOV, V. N. [1929]. Marxismo e Filosofia da Linguagem: problemas fundamentais do método sociológico da linguagem. 12. ed. São Paulo: Hucitec, 2006.

BAKHTIN, M. M. [1979]. Estética da criação verbal. Tradução do russo por Paulo Bezerra. 4. ed. São Paulo: Martins Fontes, 2003.

BARTHOLOMAE, D. Inventing the University. In: ROSE, M. (Ed.). When a writer can't write: studies in writer's block and others composing process problems. New York: Guilford Press, 1985. p. 273-285.

BEVILAQUA, R. Novos Estudos do Letramento e Multiletramentos: divergências e confluências. RevLet: Revista Virtual de Letras, v. 5, n. 1, p. 99-114, 2013.

BRAIT, B. Análise e Teoria do Discurso. In: BRAIT, B. (Org.). Bakhtin: outros conceitos-chave. São Paulo: Contexto, 2006. p. 9-31.

BRASIL. Ministério da Saúde. Conselho de Ética em Pesquisa. Certificado de Apresentação para Apreciação Ética, CAAE n. 82379918.3.0000.5564. Disponível em: http://portal2.saude.gov.br/sisnep/cep/caae. Acesso em: 12 maio 2018.

DANIELS, H. Vygotsky e a Pedagogia. São Paulo: Loyola, 2003.

DAVIDOV, V. La Enseñanza Escolar y el Desarrollo Psíquico: Investigación psicológica teórica y experimental. Moscou: Editorial Progreso, 1988.

FAIRCLOUGH, N. A Dialética do Discurso. In: MAGALHÃES, I. (Org.). Discursos e Práticas de Letramento: pesquisa etnográfica e formação de professores. São Paulo: Mercado de Letras, 2012. p. 93-110.

FERREIRA, S. A. Identidades Sociais de Raça, Multiletramentos e a Prática Pedagógica do Professor de Língua Inglesa. 2016. 319 f. (Doutorado em Letras) - Universidade Estadual do Oeste do Paraná, Cascavel, 2016.

FREIRE, P. Pedagogia da Autonomia: saberes necessários à prática educativa. São Paulo: Paz e Terra, 1996. Disponível em: http://capesdw.capes. gov.br/capes dw/. Acesso em: 10 nov. 2017. 
FREIRE, P. Educação e Atualidade Brasileira. 3. ed. São Paulo: Cortez; Instituto Paulo Freire, 2003.

FREIRE, P. Pedagogia do Oprimido. 8. ed. Rio de Janeiro: Paz e Terra, 1980.

FREIRE, P. (1982). A importância do Ato de Ler: em três artigos que se completam. 17. ed. São Paulo: Cortez, 1987.

GASPARIN, J. L. Uma Didática para a Pedagogia Histórico-crítica. Campinas, SP: Autores Associados, 2007.

HALL, S. A Identidade Cultural na Pós-modernidade. Rio de Janeiro: DP\&A, 1997.

HANKS, W. F. Foreword. In: LAVE, J.; WENGER, E. Situated Learning: legitimate peripheral participation. New York: Cambridge University Press, 1991. p. 13-26.

HEEMANN, C. A Formação de uma Comunidade Virtual de Aprendizagem sob a Perspectiva da Teoria da Atividade. Tese (Doutorado em Estudos Linguísticos) - Universidade Católica de Pelotas, Pelotas, 2010.

KLEIMAN, A. B. Trajetórias de Acesso ao Mundo da Escrita: relevância das práticas não escolares de letramento para o letramento escolar. Perspectiva, Florianópolis, v. 28, n. 2, p. 375-400, jul./dez. 2010. https://doi.org/10.5007/2175-795X.2010v28n2p375

KLEIMAN, A. B. Modelos de letramento e as práticas de alfabetização na escola. In: KLEIMAN, A. B. (Org.). Os Significados do Letramento: uma nova perspectiva sobre a prática social da escrita. Campinas: Mercado das Letras, 2008.

KLEIMAN, A. B. Processos Identitários na Formação Profissional: o professor como agente de letramento. In: CORRÊA, Manoel L. G.; BOCH, Françoise (Org.). Ensino de língua: representação e letramento. Campinas, SP: Mercado de Letras, 2006.

KRAEMER, M. A. D. Letramento Acadêmico/Científico e Participação Periférica Legítima: estudo etnográfico em comunidades de prática jurídica. Bakhtiniana: Revista de Estudos do Discurso, v. 9, p. 92-110, 2014a. https://doi.org/10.1590/S2176-45732014000200007

KRAEMER, M. A. D. Reflexão sobre o Trabalho Docente: o conhecimento construído na formação continuada e a prática pedagógica. Santa Rosa: FEMA, 2014b.

LAKATOS, E. Maria; MARCONI, M. de Andrade. Fundamentos de Metodologia Científica: Técnicas de pesquisa. 5. ed. São Paulo: Atlas, 2003.

LAVE, J.; WENGER, E. Situated Learning: legitimate peripheral participation. Cambridge: Cambridge University Press, 1991. https://doi.org/10.1017/CBO9780511815355

LEA, M. R.; STREET, B. V. Student writing in higher education: an academic literacies approach. Studies in Higher Education, v. 23, n. 2, p. 157-172, jun. 1998. https://doi.org/10.1080/03075079812331380364

LEONTIEV, A. O Desenvolvimento do Psiquismo. 2. ed. São Paulo: Centauro, 2004.

LURIA, A. R.; LEONTIEV, A.; VIGOTSKI, L. S. et al. Psicologia e Pedagogia I: bases psicológicas da aprendizagem e do desenvolvimento. Lisboa: Estampa, 1977.

MAGALHÃES, M. C. C. A Linguagem na Formação de Professores como Profissionais Reflexivos e Críticos. In: MAGALHÃES, M. C. C. (Org.). A Formação do Professor como um 
Profissional Crítico: linguagem e reflexão. 2. ed. Campinas, SP: Mercado de Letras, 2009. p. 45-62.

MÁRKUS, G. Marxismo y "Antropología". Barcelona: Grijalbo, 1974.

MARX, K. Manuscritos Econômico-filosóficos. Tradução de Jesus Ranieri. 2. reimpr. São Paulo: Boitempo, 2008.

MOITA LOPES, L. P. Linguagem, Interação e Formação de Professores. Revista Brasileira de Estudos Pedagógicos - INEP, Brasília, v. 75, n. 179/180/181, p. 301-371, jan./dez. 1994.

MOITA LOPES, L. P. Tendências Atuais da Pesquisa na Área de Ensino/Aprendizagem de Línguas no Brasil. Letras, Santa Maria, v. 4, p. 7-13, jul./dez. 1992.

MOTTA-ROTH, D. Desenvolvimento do Letramento Acadêmico por Engajamento em Práticas Sociais na Universidade. In: VIAN JR. O.; CALTABIANO, C. (Orgs.). Língua(Gem) e suas Múltiplas Faces: estudos em homenagem a Leila Bárbara. São Paulo: Mercado de Letras, 2013.

RUBINSTEIN, S. L. O estudo. In: RUBINSTEIN, S. L. Princípios da Psicologia Geral VI. Lisboa: Editorial Estampa, 1977. p.130-161.

SOARES, M. Letramento: um tema em três gêneros. Belo Horizonte: Autêntica, 2003.

STREET, B. Letramentos Sociais: abordagens críticas do letramento no desenvolvimento, na etnografia e na educação. São Paulo: Parábola Editorial, 2014.

STREET, B. Eventos de Letramento e Práticas de Letramento: teoria e prática nos novos estudos do letramento. In: MAGALHÃES, I. (Org.). Discursos e Práticas de Letramento: pesquisa etnográfica e formação de professores. São Paulo: Mercado de Letras, 2012. p.6992.

STREET, B. Perspectivas Interculturais sobre Letramento. Trad. Marcos Bagno. Filologia, Linguística, Português, n. 8, p. 465-488, 2006. https://doi.org/10.11606/issn.21769419.v0i8p465-488

STREET, B. What's "New" in New Literacy Studies? Critical approaches to literacy in theory and practice. Current Issues in Comparative Education, Londres, maio, 2003a. Disponível em: https://www.tc.columbia.edu/cice/pdf/25734_5_2_Street.pdf. Acesso em: 10 out. 2017.

STREET, B. Abordagens Alternativas ao Letramento e Desenvolvimento. Teleconferência Unesco Brasil sobre o Letramento e Diversidade, outubro de 2003b. Disponível em http://telecongresso.sesi.org.br. Acesso em: 10 nov. 2003.

UNIVERSIDADE FEDERAL DA FRONTEIRA SUL. Projeto Pedagógico do Curso de Graduação em Letras, Português e Espanhol, Licenciatura. Chapecó: UFFS, 2010. Disponível em: file:///C:/Users/Usuario/Downloads/PPC_Letras.pdf. Acesso em: 10 mar. 2018.

UNIVERSIDADE FEDERAL DA FRONTEIRA SUL. Edital № 14/PROGRAD/UFFS/2018.

Resultado Final do Edital № 04/PROGRAD/UFFS/2018. Seleção de Projetos de Monitoria de Ensino UFFS/2018.2 e 2019.1. Chapecó: UFFS, 2018. Disponível em: https://www.uffs.edu.br/atos-normativos/edital/prograd/2018-0014. Acesso em: 19 jun. 2018.

WENGER, E. Communities of Practice: learning, meaning, and identity. New York: Cambridge University Press, 1998. https://doi.org/10.1017/CBO9780511803932 
VOLOCHínOV, V.N. A Construção da Enunciação e Outros Ensaios. São Carlos: Pedro \& João, 2013.

VIGOTSKI, L. S. [1934]. A Construção do Pensamento e da Linguagem. São Paulo: Martins Fontes, 2001.

Recebido em: 15/03/2019

Aceito em: 01/07/2019 